\title{
Topical application of mitomycin C as an adjunct in treating subglottic stenosis
}

Miejscowe zastosowanie mitomycyny C jako środka wspomagającego

\author{
w leczeniu zwężenia podgłośniowego
}

\author{
'Department of Otorhinolaryngology - Head and Neck Surgery, Universiti Sains Malaysia, Kubang Kerian, 16150, Kelantan, Malaysia \\ ${ }^{2}$ Department of Otorhinolaryngology - Head and Neck Surgery, Penang General Hospital, Georgetown 10990, Pulau Pinang, Malaysia \\ ${ }^{3}$ Hospital Universiti Sains Malaysia, Health Campus, 16150 Kota Bharu, Kelantan, Malaysia \\ Correspondence: Irfan Mohamad, Department of Otorhinolaryngology - Head and Neck Surgery, Hospital Universiti Sains Malaysia, Health Campus, 16150 Kota Bharu, Kelantan, Malaysia, \\ e-mail: irfankb@usm.my
}

Abstract Topical application of mitomycin C is best used as an adjunct in airway surgeries together with combination of other modalities of endoscopic techniques such as excision, balloon dilatation and laser treatment in treating subglottic stenosis. We present a case of a 12-year-old boy who acquired Cotton-Myer grade 3 subglottic stenosis 6 months post endotracheal intubation. The stenotic segment was treated with cautery-assisted excision followed by balloon dilatation and topical application of mitomycin $\mathrm{C}$ at the raw area. The patient recovered well with improvement of airway diameter, no more symptoms, no more events of restenosis and without the need for multiple procedures.

Keywords: subglottic stenosis, mitomycin C, flexible nasopharyngolaryngoscopy

Streszczenie Mitomycyna C w zastosowaniu miejscowym jest z powodzeniem używana jako wsparcie zabiegów endoskopowych wykonywanych w leczeniu zwężenia podgłośniowego, takich jak wycięcie, poszerzanie z zastosowaniem cewnika balonowego, laserotarapia. W pracy przedstawiono przypadek 12-letniego chłopca, u którego 6 miesięcy po intubacji dotchawiczej doszło do zwężenia podgłośniowego III stopnia w skali Cottona-Myera. Zwężony odcinek leczono metodą wycięcia z kauteryzacją, a następnie poszerzano z zastosowaniem cewnika balonowego. Na świeżo operowane miejsce zastosowano miejscowo mitomycynę C. Zabieg zakończył się sukcesem - uzyskano poprawę średnicy dróg oddechowych przy jednoczesnym braku objawów, nawrotów zwężenia i konieczności powtarzania zabiegu.

Słowa kluczowe: zwężenie podgłośniowe, mitomycyna C, laryngoskopia giętka nosogardła 


\section{INTRODUCTION}

$\mathrm{T}$ reating a patient with subglottic stenosis remains a challenge due to the scarring process and restenosis leading to failure of interventions. The goal of treatment is to achieve an adequate airway, a satisfactory voice and restoring the protective function of larynx against aspiration. This can only be restored when a good modulation of wound healing is established by preventing excessive scarring. Mitomycin $\mathrm{C}$ is an antitumour antibiotic as well as an antiproliferative agent that inhibits fibroblast activity and promotes the role of mitomycin $\mathrm{C}$ as an adjunct in effective treatment of subglottic stenosis ${ }^{(1,2)}$.

\section{CASE SUMMARY}

A 12-year-old boy was referred for hoarseness and choking episodes during feeding since extubation. He had history of intubation for a week while being treated for nosocomial sepsis with leptospirosis one month prior to this presentation. Post extubation, he was monitored in the intensive care unit (ICU) for 3 weeks and his symptoms started immediately post extubation. During his visit to the clinic, the patient reported that hoarseness was relatively improving. He denied having noisy breathing at rest or at exertion. He also denied having shortness of breath. He was fed via a nasogastric tube as he failed bedside swallowing assessment during his ICU stay.

His clinical examination was unremarkable. There was no abnormality found during the routine examination of ear, nose and neck. Flexible nasopharyngolaryngoscopy (FNPLS) noted a compensated left vocal cord immobility. Fiberoptic endoscopic evaluation of swallowing (FEES) performed on the same visit demonstrated no fluid aspiration or penetration. His sensation at supraglottic area was intact. Thus he was allowed to tolerate feeding orally.

He was seen again after 4 months with noisy breathing, complaining of shortness of breath during exertion, reducing his effort tolerance. His oxygen saturation was maintained at $100 \%$ with stable vitals. FNPLS was performed and showed that his both vocal cords were mobile, but the subglottic region was stenosed.

He was admitted and started on intravenous dexamethasone. Urgent contrast-enhanced computed tomography demonstrated stenotic segment present at $2.2 \mathrm{~cm}$ below the vocal cords (Fig. 1).

Subsequently, the patient underwent direct laryngoscopy, bronchoscopy, cautery-assisted excision, balloon dilatation and mitomycin $\mathrm{C}$ application under general anaesthesia. Intraoperatively, the subglottic stenosis was graded as Cotton-Myer grade 3, $2.2 \mathrm{~cm}$ below the vocal cords, measuring around $0.5 \mathrm{~cm}$ in length with a $3 \mathrm{~mm}$-diameter opening. The stenotic segment was excised with assistance of cautery at 12, 4 and 7 o'clock. Post excision, dilatation was performed with size 14 balloon inflated to

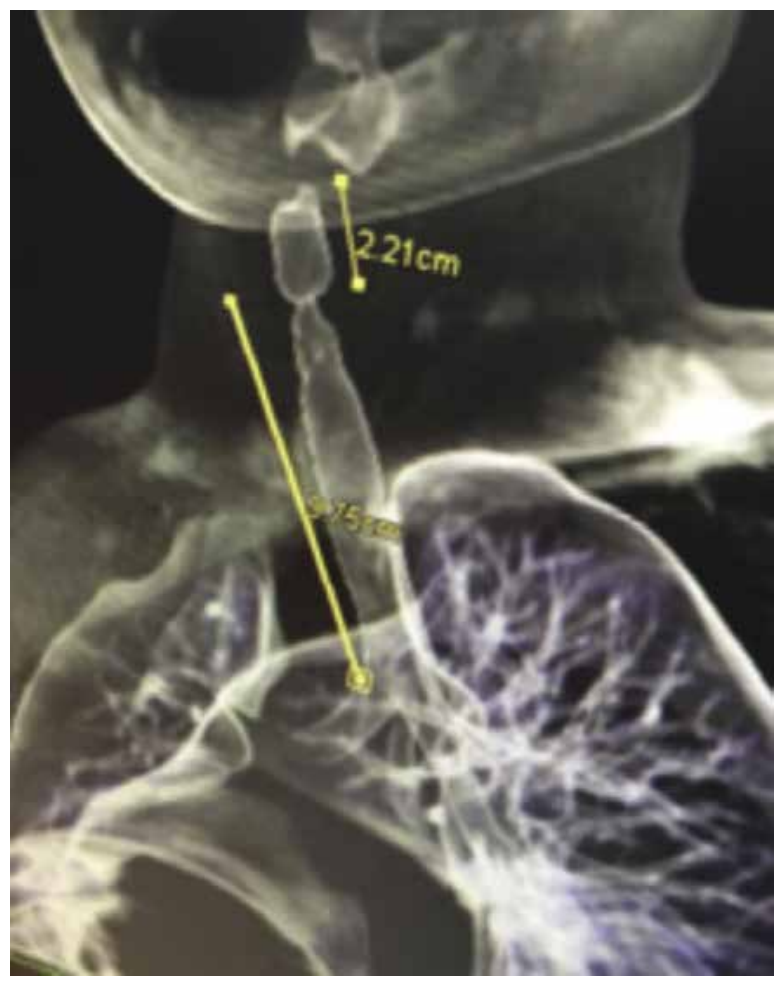

Fig. 1. A 3D-image of the stenotic segment measuring around $0.5 \mathrm{~cm}$ in length, located at $2.2 \mathrm{~cm}$ below the vocal cords

soaked with $0.4 \mathrm{mg} / \mathrm{mL}$ mitomycin $\mathrm{C}$ was applied at the raw area. The ribbon gauze was left in situ for 2 minutes before it was removed.

After the procedure, he was monitored in the ICU and kept ventilated for 4 days. He was transferred from the ICU a week after. He recovered well without any complications. Repeated FNPLS and bronchoscopy findings were unremarkably normal without subglottic stenosis. He was still symptom-free with normal findings on laryngoscopy after one year.

\section{DISCUSSION}

The subglottic region is the narrowest part of the paediatric airway. It extends from the inferior margin of the vocal cords to the lower border of cricoid cartilage and it is bounded circumferentially by the cricoid cartilage. Endotracheal intubation is the most common cause, amounting approximately $90 \%$ of all cases of acquired subglottic stenosis ${ }^{(3)}$. The reported incidence of acquired subglottic stenosis post intubation is between $2.8-11.3 \%{ }^{(4)}$. These patients requiring prolonged ventilation have mucosal ischaemia and ulceration of the surrounding laryngeal and tracheal wall due to long-term placement of the endotracheal tube (ETT). When healing occurs, a varying degree of stenosis is formed by a firm fibrous scar, typically circumferential ${ }^{(5)}$.

Other causes of subglottic stenosis are airway trauma such as inappropriate size of ETT, inhalation burns, irradiations and chronic infections such as sarcoidosis, lupus 
erythematosus, Behçet's syndrome, Wegener's granulomatosis, relapsing polychondritis and amyloidosis ${ }^{(3,5)}$.

Treatment of subglottic stenosis is individualised according to patient's age, degree and consistency of stenosis, the percentage of stenosis, general patient's condition and the availability of expertise and instruments. This includes the well-accepted open reconstruction of the laryngotracheal framework or the evolving and expanding endoscopic technique. Endoscopic techniques include balloon dilatation, laser treatment, electrocautery-assisted surgery, cryotherapy and stent placement.

These surgical and endoscopic interventions can lead to a vicious cycle of mucosal disruption, healing and granulation tissue formation $^{(6)}$, which may result in restenosis. Thus much care and attention should be put into managing a patient with subglottic stenosis to prevent restenosis after surgical interventions. We chose to use the minimally invasive and available endoscopic technique to perform cautery-assisted excision followed by balloon dilatation. Mitomycin $\mathrm{C}$ was applied on the raw area to prevent further fibroblast proliferation.

Adjuvant therapy is now actively investigated to improve and prevent restenosis and this includes topical application of mitomycin C. Topical mitomycin $\mathrm{C}$ is widely used as an adjunct in ophthalmological surgery, such as pterygium removal surgeries and glaucoma surgeries. Due to the property of mitomycin $\mathrm{C}$ that enables it to inhibit the proliferation of fibroblasts with minimal exposure of 5 minutes in low concentrations, it is an excellent adjunct in airway surger $\mathrm{y}^{(7)}$. Mitomycin $\mathrm{C}$ is an antitumour antibiotic derived from Streptomyces caespitosus. It is an alkylating agent that targets specifically the guanine nucleoside sequence 5'-CpG-3'. Mitomycin C produces interstrand DNA cross-links between complementary strands, thus preventing separation of these complementary DNA strands and inhibiting DNA replication. Mitomycin C also inhibits RNA synthesis and protein synthesis at high concentrations ${ }^{(7,8)}$. The existing controversy on the use of mitomycin $\mathrm{C}$ is related to the exposure time, mode of delivery and the optimum concentration of mitomycin C. Mitomycin C at a concentration of $1 \mathrm{mg} / \mathrm{mL}$, which is higher than the usual concentration, was reported to be effective in treating oesophageal stricture and tracheobronchial stricture without any complications during follow-up ${ }^{(8)}$.

Release of laryngeal scars together with application of topical mitomycin $\mathrm{C}$ increases the efficacy of balloon dilatation by prolonging the time for restenosis by inhibiting scar tissue growth ${ }^{(9)}$. The rate of suspected complications was $1.1 \%$ in 93 applications and it was cost-effective ${ }^{(7)}$. The successful application of mitomycin $\mathrm{C}$ to prevent excessive wound healing was demonstrated in 5 difficult cases with continuous intraluminal scar tissue growth and recalcitrant airway stenosis post reconstruction surgery ${ }^{(10)}$.

Despite its success rates, local toxicity of mitomycin $\mathrm{C}$ with accumulation of fibrinous debris and delayed wound healing remains the main reason why surgeons walk away from using mitomycin C. Roh et al. described that mitomycin C delays wound healing when applied to mucosal defects of full thickness depth compromising the blood supply and thus causing partial necrosis of the cartilage underneath the unhealing mucosal layer ${ }^{(11)}$. Thus the involvement of the cartilaginous part in the stenosis should be evaluated before considering the use of mitomycin C.

The patient's previous vocal cord immobility post extubation that achieved normal mobility is probably associated with posterior commissure or arytenoid oedema that follows a spontaneous resolution in days-to-weeks' time ${ }^{(12)}$.

\section{CONCLUSION}

Subglottic stenosis post intubation can be successfully treated with cautery assisted excision, balloon dilatation and $\mathrm{mi}-$ tomycin C application. Mitomycin C works best as an adjunct in airway surgery when it is accompanied by other modalities of endoscopic treatment in subglottic stenosis of membranous type. The best results are achieved by using the appropriate dose, delivery method and exposure time of mitomycin $\mathrm{C}$ that causes minimal complications and reduced rate of restenosis at lowest possible costs.

\section{Conflict of interest}

All authors declare that there is no conflict of interest.

\section{References}

1. Quesnel AM, Lee GS, Nuss RC et al.: Minimally invasive endoscopic management of subglottic stenosis in children: success and failure. Int J Pediatr Otorhinolaryngol 2011; 75: 652-656.

2. Hueman EM, Simpson CB: Airway complications from topical mitomycin C. Otolaryngol Head Neck Surg 2005; 133: 831-835.

3. Garnett JD: Subglottic stenosis in adults. eMedicine Medscape, Otolaryngology and Facial Plastic Surgery. 2010.

4. Schweiger C, Manica D, Pereira DRR et al.: Undersedation is a risk factor for the development of subglottic stenosis in intubated children. J Pediatr (Rio J) 2017; 93: 351-355.

5. Zalzal GH, Cotton RT: Glottic and subglottic stenosis. In: Cummings CW: Otolaryngology Head and Neck Surgery. $2^{\text {nd }}$ ed., Mosby, St Louis 1993: 303-324.

6. Penafiel A, Lee P, Hsu A et al.: Topical mitomycin-C for obstructing endobronchial granuloma. Ann Thorac Surg 2006; 82: e22-e23.

7. Ubell ML, Ettema SL, Toohill RJ et al.: Mitomycin-c application in airway stenosis surgery: analysis of safety and costs. Otolaryngol Head Neck Surg 2006; 134: 403-406.

8. Daher P, Riachy E, Georges B et al.: Topical application of mitomycin $\mathrm{C}$ in the treatment of esophageal and tracheobronchial stricture: a report of 2 cases. J Pediatr Surg 2007; 42: e9-e11.

9. Vira D, DeConde A, Chhetri DK: Endoscopic management of supraglottic laryngopharyngeal stenosis. Otolaryngol Head Neck Surg 2012; 146: 611-613.

10. Ward RF, April MM: Mitomycin-C in the treatment of tracheal cicatrix after tracheal reconstruction. Int J Pediatr Otorhinolaryngol 1998; 44: 221-226.

11. Roh JL, Kim DH, Rha KS et al.: Benefits and risks of mitomycin use in the traumatized tracheal mucosa. Otolaryngol Head Neck Surg 2007; 136: 459-463.

12. Whited RE: Laryngeal dysfunction following prolonged intubation. Ann Otol Rhinol Laryngol 1979; 88: 474-478. 